\title{
Pengaruh Environmental Performance Terhadap Environmental Disclosure dan Economic Performance (Studi Empiris pada Perusahaan Pertambangan yang Terdaftar Di BEI)
}

\author{
Dedi Putra \\ Jurusan Akuntansi Fakultas Ekonomi dan Bisnis, IIB Darmajaya \\ e-mail : dedi_kmh@yahoo.com \\ Indah Lutfia Utami \\ Jurusan Akuntansi Fakultas Ekonomi dan Bisnis, IIB Darmajaya \\ e-mail : ilutfiautami@gmail.com
}

\begin{abstract}
This study was aimed at demonstrating empirically the Influence of Environmental Performance on Environmental Disclosure and Economic Performance. The dependent variables in this research were the Environmental Disclosure and Economic Performance, while the independent variable was the Environmental Performance. The data collection method used purposive sampling. The study sample was ten mining companies listed on the Indonesia Stock Exchange and had a PROPER rate from the Ministry of Environment in 2011-2015. The data used in this research was secondary data. The data was analyzed using simple regression, Eviews ver 4.1. The results showed that the Environmental Performance significantly influence Environmental Disclosure and Economic Performance.
\end{abstract}

Keywords: Environmental Performance, Environmental Disclosure, Economic Performance

\section{Pendahuluan}

Isu lingkungan menjadi masalah penting di berbagai negara khususnya di Indonesia. Permasalahan lingkungan terus menjadi sorotan serta perbincangan, dan saat ini dalam dunia bisnis terjadi peningkatan usaha dalam hal pengelolaan serta pelestarian lingkungan. Hal ini disebabkan adanya dorongan dari luar perusahaan. Pada beberapa tahun terakhir ini, Indonesia mengalami peningkatan permasalahan pencemaran lingkungan hidup (Suratno, 2006) terlihat pada grafik di bawah ini yang menyatakan bahwa tingkat Total Suspended Solid (TSS) semakin tinggi ini mengindikasi bahwa kondisi lingkungan di Indonesia semakin buruk, banyak kejadian kerusakan lingkungan sehingga laju erosi semakin besar. 


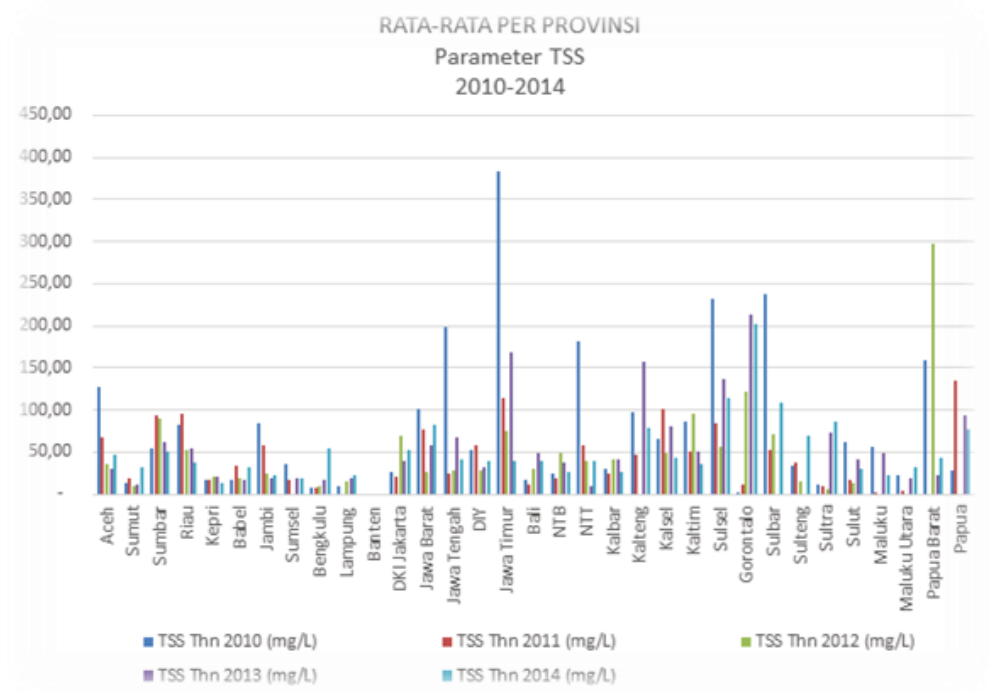

Gambar 1

\section{Rata-rata Total Suspended Solid Di setiap Provinsi terkait kerusakan Lingkungan Sumber : Statistik Kementerian Lingkungan Hidup, 2014}

Isu lingkungan bukan lagi merupakan suatu isu yang baru. Persoalan lingkungan semakin menarik untuk dikaji seiring dengan perkembangan teknologi dan ekonomi global dunia. Secara perlahan terjadi perubahan yang mendasar dalam pola hidup bermasyarakat yang secara langsung atau tidak memberikan pengaruh pada lingkungan hidup. Indonesia sebagai negara sedang berkembang tidak terlepas pula dari persoalan lingkungan yang semakin hari semakin terasa dampaknya. Era industrialisasi di satu pihak menitikberatkan pada pengunaan teknologi seefisen mungkin sehingga terkadang mengabaikan aspek-aspek lingkungan. Kesadaran masyarakat Indonesia akan pentingnya arti lingkungan mulai tumbuh secara perlahan-lahan. Kesadaran ini tentunya menjadi modal dasar sebagai sistem kontrol bagi perusahaan-perusahaan sehingga efek samping industrialisasi perusahaan dapat termarjinalkan. Aktualisasi kesadaran ini mulai kelihatan dengan gencarnya reaksi masyarakat terhadap perubahan yang terjadi dari suatu sistem (Fitriana, 2013).

Penyebab timbulnya permasalahan pencemaran lingkungan di Indonesia perlu dikaji secara mendalam supaya dapat dilakukan tindakan pencegahan dan perbaikan yang tepat. Usaha dari pihak regulasi untuk melestarikan dan mengembangkan kemampuan lingkungan hidup yang serasi, selaras, dan seimbang telah dilakukan dengan menetapkan Undang-Undang Republik Indonesia Nomor 32 Tahun 2009 tentang Perlindungan dan Pengelolaan Lingkungan Hidup (UUPPLH) adalah upaya sistematis dan terpadu yang dilakukan untuk melestarikan fungsi lingkungan hidup dan mencegah terjadinya pencemaran dan/atau kerusakan lingkungan hidup yang meliputi pencemaran, pemanfaatan, pengendalian, pengawasan, dan penegakan hukum. Pemerintah melalui Kementerian Lingkungan Hidup bahkan telah membentuk program yang disebut dengan PROPER sebagai bentuk penaatan lingkungan hidup perusahaanperusahaan di Indonesia. Hal ini dilakukan dalam hal menilai kinerja lingkungan perusahaan dan memacu agar perusahaan semakin baik dalam usaha peduli terhadap 
lingkungan. Respon baik atas program PROPER sebagai penilaian kinerja lingkungan perusahaan terus meningkat (www.mnlh.go.id).

Perusahaan merupakan suatu alat yang dipergunakan seseorang atau kelompok tertentu untuk mendapatkan keuntungan semaksimal mungkin. Namun beberapa perusahaan juga harus memperhatikan lingkungan sekitar. Seperti fenomena yang terjadi pada anak Perusahaan Bayan Resources, yang aktivitas perusahaannya merusak lingkungan di daerah Pesut Mahakam, Kalimantan Timur(sindonews.com, 9 Juli 2015).

Seperti fenomena di atas, banyak dampak negatif yang dihadapi perusahaan pertambangan yakni diantaranya dapat merusak ekosistem hutan sehingga dapat menyebabkan kerusakan lingkungan dalam bentuk pencemaran air, tanah, dan udara yang disebabkan oleh benda-benda asing sebagai akibat perbuatan manusia, sehingga mengakibatkan lingkungan tersebut tidak berfungsi seperti semula. Di sisi lain, dampak positif yang ditimbulkan juga sangat besar yaitu meningkatnya devisa negara dan pendapatan asli daerah serta menampung tenaga kerja. Masyarakat sekitar dapat memperoleh pekerjaan dari pertambangan tersebut. Environmental performance (Kinerja Lingkungan) adalah mekanisme bagi perusahaan untuk secara sukarela mengintegrasikan perhatian terhadap lingkungan ke dalam operasinya dan interaksinya dengan stakeholders, yang melebihi tanggung jawab organisasi di bidang hukum. Environmental disclosure adalah pengungkapan informasi sukarela, baik secara kualitatif maupun kuantitatif yang dibuat oleh organisasi untuk menginformasikan aktivitasnya, di mana pengungkapan kuantitatif berupa informasi keuangan maupun nonkeuangan. Dengan melihat environmental disclosure ini, dapat diketahui perusahaan mana saja yang telah menerapkan tanggung jawab sosialnya. Economic Performance (Kinerja Ekonomi) adalah kinerja perusahaan yang secara relatif dalam suatu kelompok industri sejenis yang ditandai dengan return tahunan perusahaan tersebut (Suratno, 2006). Kinerja ekonomi yang baik dapat membuat gambaran perusahaan bahwa telah mendapatkan keberhasilan, dilihat dengan cara menganalisis kondisi keuangan perusahaan. Namun, tidak hanya menuntut terciptanya kinerja ekonomi yang hanya memfokuskan pada terciptanya keuntungan yang besar bagi perusahaan, tetapi juga perlu disertai dengan perilaku kinerja ekonomi yang bersifat etis. Seperti kinerja perusahaan yang memperhatikan tanggung jawab sosialnya terhadap lingkungan yang berada di sekitar perusahaan. Demikian dapat disimpulkan bahwa kinerja ekonomi perusahaan merupakan sinyal positif bagi kalangan pemilik modal seperti para investor untuk menanamkan dananya ke dalam perusahaan (Wibisono, 2011).

Penelitian empiris mengenai hubungan antara environmental performance, economic performance, dan environmental disclosure secara umum telah mempertimbangkan kekuatan hubungan di antara variabel-variabel tersebut. Ingram dan Frazier (1980) menemukan tidak adanya hubungan yang signifikan dalam pengujian hubungan antara environmental disclosure dengan environmental performance. Pattern (2002) menemukan hubungan yang negatif antara environmental disclosure dalam annual report dengan environmental performance. Al-Tuwaijri, et al.,(2004) menemukan adanya hubungan positif signifikan antara economic performance dengan environmental performance, demikian juga antara environmental disclosure dengan environmental performance. Al-Tuwaijri, et al. (2004) merupakan peneliti yang memasukkan konsep economic performance sebagai variabel endogenous dalam model penelitian yang digunakan bersama dengan dua variabel endogenous lainnya. Penelitian-penelitian empiris tersebut menampakkan hasil yang masih beragam. Hal ini dimungkinkan sampel penelitian dan lokasi penelitian yang beragam. Tujuan dari 
penelitian ini adalah untuk membuktikan secara empiris pengaruh environmental performance terhadap environmental disclosure dan economic performance.

Adanya fakta permasalahan pencemaran lingkungan yang dilakukan oleh perusahaan pertambangan di Indonesia maka diajukan pemasalahan penelitian sebagai berikut:

1. Apakah environmental performance memiliki pengaruh terhadap environmental disclosure?

2. Apakah environmental performance memiliki pengaruh terhadap economic performance?

\section{Kerangka Teroritis}

Legitimasi theory merupakan keadaan psikologis keberpihakan orang dan kelompok orang yang sangat peka terhadap gejala lingkungan sekitarnya baik fisik maupun nonfisik. O'Donovan (2002) berpendapat legitimasi organisasi dapat dilihat sebagai sesuatu yang diberikan masyarakat kepada perusahaan dan sesuatu yang diinginkan atau dicari perusahaan dari masyarakat. Dengan demikian, legitimasi merupakan manfaat atau sumber daya potensial bagi perusahaan untuk bertahan hidup (going concern). Sejalan dengan karakternya yang berdekatan dengan ruang dan waktu, legitimasi mengalami pergeseran bersamaan dengan perubahan dan perkembangan lingkungan dan masyarakat dimana perusahaan berada (Dowling 1975) dalam buku Hadi (2011:87).

Kinerja lingkungan merupakan satu langkah penting perusahaan dalam meraih kesuksesan. Kinerja lingkungan dapat diukur melalui sistem manajeman lingkungan. Menurut Handayani (2010), semakin banyak perusahaan berperan di dalam kegiatan lingkungan, akan semakin banyak pula yang harus diungkapkan oleh perusahaan mengenai kinerja lingkungan yang dilakukannya dalam laporan tahunannya. Hal ini akan mencerminkan transparansi dari perusahaan tersebut bahwa perusahaan juga berkepentingan dan bertanggung jawab terhadap apa yang telah dikerjakannya sehingga masyarakat juga akan tahu seberapa besar andil perusahaan terhadap lingkungannya. Penelitian ini juga didukung oleh Suratno (2006).

Jadi semakin banyak perusahaan berperan di dalam kegiatan lingkungan, akan semakin banyak pula yang harus diungkapkan oleh perusahaan mengenai kinerja lingkungan yang di lakukannya dalam laporan tahunannya. Hal ini akan mencerminkan transparansi dari perusahaan tersebut bahwa perusahaan juga berkepentingan dan bertanggung jawab terhadap apa yang telah dikerjakannya sehingga masyarakat juga akan tahu seberapa besar andil perusahaan terhadap lingkungannya. Maka hubungan antara environmental performance dengan environmental disclosure dapat dihipotesiskan sebagai berikut:

\section{$\mathrm{H}_{1}$ : Environmental performance berpengaruh terhadap environmental disclosure.}

Dalam Suratno, Darsono, dan Mutmainah, (2006) terdapat hubungan positif signifikan antara environmental performance dengan economic performance yang dihitung dengan return saham dikurangi dengan median return industri, sehingga return saham bisa digunakan sebagai ukuran dalam economic performance.Tinggi rendahnya kinerja ekonomi suatu perusahaan dipengaruhi oleh kineja lingkungan melalui pengungkapan kinerja lingkungan tersebut (Rohmah \& Wahyudin, 2015). 
Semakin besar andil perusahaan di dalam kegiatan lingkungan, maka semakin baik pula image perusahaan di mata stakeholder maupun pengguna laporan keuangan. Dengan adanya image positif tersebut, maka akan dapat menarik perhatian dari para stakeholder maupun masyarakat pengguna laporan keuangan. Sehingga pasar akan merespon secara positif melalui fluktuasi harga saham yang diikuti oleh meningkatnya return saham perusahaan. Secara relatif banyak investor berminat untuk membeli saham perusahaan guna menanamkan investasinya, hal ini merupakan cerminan pencapaian economic performance. Maka hubungan antara environmental disclosure terhadap economic performance dapat dihipotesiskan sebagai berikut:

\section{$\mathrm{H}_{2}$ : Environmental performance berpengaruh terhadap economic performance.}

\section{Model Penelitian}

Model penelitian disajikan sebagai berikut :

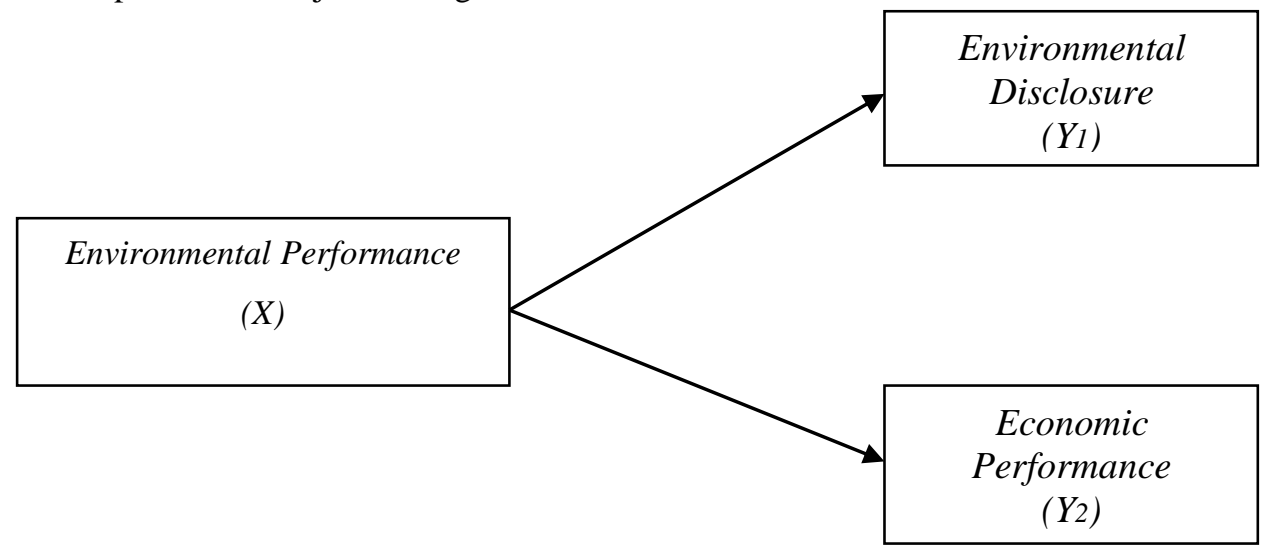

Gambar 2

Model Penelitian

\section{Metode Penelitian}

\section{Populasi dan Sampel}

Populasi dalam penelitian ini adalah Perusahaan Pertambangan yang terdaftar di Bursa Efek Indonesia (BEI) pada periode tahun 2011-2015 dan dari Kementerian Lingkungan Hidup (KLH). Dipilih dengan menggunakan purposive sampling method dengan kriteria sebagai berikut: (a) Perusahaan Pertambangan yang telah terdaftar di Bursa Efek Indonesia (BEI) tahun 2011-2015. (b) Perusahaan Pertambangan yang terdaftar di BEI dari tahun 2011-2015. (c) Perusahaan Pertambangan yang laporan keuangannya dari tahun 2011-2015 tidak delisting.(d) Perusahaan Pertambangan yang mengikuti PROPER (Program Penilaian Peringkat Kinerja Perusahaan) pada tahun 2011-2015.

\section{Variabel dan Definisi Operasional}

Variabel Dependen

Environmental Disclosure $\left(\mathbf{Y}_{1}\right)$

Environmental disclosure adalah pengungkapan informasi yang berkaitan dengan lingkungan di dalam laporan tahunan perusahaan. Dihitung dengan rumus: 
$\mathrm{ED}=\frac{\mathrm{Jmlh} \text { item yg diungkap perusahaan }}{\mathrm{Imlh} \text { item pngungkapan lingkungan }}$

\section{Economic Performance $\left(\mathrm{Y}_{2}\right)$}

Economic performance adalah kinerja perusahaan yang secara relatif dalam suatu industri yang sama yang ditandai dengan return tahunan industri yang bersangkutan (Suratno dkk, 2006). Dihitung dengan rumus (Harahap, 2008):

ROA $=\frac{\text { Laba Setelah Pajak }}{\text { Total Aktiva }}$

\section{Variabel Independen}

\section{Environmental Performance}

Environmental performance adalah kinerja perusahaan dalam menciptakan lingkungan yang baik (green) (Suratno dkk, 2006). Variabel ini diukur oleh peringkat PROPER dari Kementerian Lingkungan Hidup. Sistem peringkat kinerja PROPER mencakup pemeringkatan perusahaaan dalam lima (5) warna yang diberi skor secara berturut-turut. Skor 5 adalah warna emas, skor 4 adalah warna hijau, skor 3 adalah warna biru, skor 2 adalah warna merah dan skor 1 adalah warna hitam.

\section{Metode Pengujian Hipotesis}

Untuk menguji hipotesis yang dikembangkan dalam penelitian ini digunakan alat analisis regresi. Model persamaan struktural yang diusulkan sebagai suatu model empiris adalah sebagai berikut:

$$
\begin{aligned}
& \mathrm{ED}_{1}=\beta_{0}+\beta E V P \ldots .(1) \\
& \mathrm{EP}_{2}=\beta_{0}+\beta E V P \text {.....(2) }
\end{aligned}
$$

Keterangan:

$\mathrm{Y}_{1} \quad=$ Enviromental Disclousure

$\mathrm{Y}_{2}=$ Economic Performance

$\mathrm{X}=$ Enviromental performance

$\beta_{0} \quad=$ Konstanta

$\beta \mathrm{X}=$ Koefisien regresi dari variabel independen 


\section{Hasil Penelitian dan Pembahasan}

\section{Hasil Penelitian}

Proses pemilihan data sampel dapat dilihat dalam tabel berikut:

Tabel 1

Proses Seleksi Berdasarkan Kriteria

\begin{tabular}{|l|c|}
\hline \multicolumn{1}{|c|}{ Keterangan } & Jumlah \\
\hline $\begin{array}{l}\text { Perusahaan Pertambangan yang terdaftar di Bursa Efek } \\
\text { Indonesia selama tahun 2011-2015 }\end{array}$ & 44 \\
\hline $\begin{array}{l}\text { Mempublikasikan laporan keuangan tahunan (annual report) } \\
\text { lengkap dan tidak delisting selama tahun 2011-2015 }\end{array}$ & $(34)$ \\
\hline $\begin{array}{l}\text { Perusahaan yang mengikuti PROPER (Penilaian Peringkat } \\
\text { Kinerja Perusahaan) pada tahun 2011-2015 }\end{array}$ & $(10)$ \\
\hline $\begin{array}{l}\text { Jumlah Perusahaan Pertambangan yang dijadikan sampel } \\
\text { penelitian }\end{array}$ & $\mathbf{1 0}$ \\
\hline Jumlah Observasi (5 tahun penelitian x 10 sampel) & $\mathbf{5 0}$ \\
\hline
\end{tabular}

Sumber: Bursa Efek Indonesia dan Peringkat PROPER

Tabel 2

Descriptive Statistics

\begin{tabular}{|c|c|c|c|c|c|}
\hline & $\mathrm{N}$ & Minimum & Maximum & Mean & $\begin{array}{c}\text { Std. } \\
\text { Deviation }\end{array}$ \\
\hline Environmental Diclosure & 50 &, 2432 &, 5000 &, 401348 &, 0499918 \\
Economic Performance & 50 &,- 1632 &, 5349 &, 081706 &, 1297854 \\
Environmental & 50 & 2 & 5 & 3,44 &, 705 \\
Performance & 50 & & & & \\
Valid N (listwise) & & & \\
\hline
\end{tabular}

Sumber : Data Sekunder diolah dengan Eviews 7

Jumlah sampel variabel adalah 50 sampel. Dari hasil pengolahan data dilihat bahwa nilai terendah variable dependen Environmental Disclosure $\left(\mathrm{Y}_{1}\right)$ adalah sebesar 0,2432 yang dimiliki perusahaan Indo Tambang Raya MegahTbk di tahun 2011. Sementara nilai tertinggi Environmental Disclosure sebesar 0,5000 yang dimiliki perusahaan Indo Tambang Raya Megah Tbk ditahun 2015, dengan nilai rata-rata Environmental Disclosure sebesar 0,401348 dan standar deviasi sebesar 0,0499918. Dari hasil pengolahan data dilihat bahwa nilai terendah variable dependen Economic Performance $\left(\mathrm{Y}_{2}\right)$ sebesar -0,1632 yang dimiliki perusahaan Bayan Resources Tbkditahun 2015. Sementara nilai tertinggi Economic Performance sebesar 0,5349 dimiliki perusahaan Timah (Persero) Tbk di tahun 2011dengan nilai rata-rata Economic Performance sebesar 0,081706 dan standar deviasi 0,1297854. Dari hasil pengolahan data dilihat bahwa nilai terendah variable independen Environmental Performance (X) sebesar 2 dimiliki perusahaan Vale Indonesia Tbk ditahun 2012. Sementara nilai tertinggi Environmental Performance sebesar 5 dimiliki perusahaan Medco Energy International Tbk dan Adaro Energy Tbk dengan nilai rata-rata Environmental Performance sebesar 3,44 dan standar deviasi sebesar 0,705. 


\section{Pengujian Hipotesis}

\begin{tabular}{ccccc}
\hline \hline Variable & Coefficient & Std. Error & t-Statistic & Prob. \\
\hline \hline$C$ & 0.323746 & 0.034082 & 9.498942 & 0.0000 \\
$X \rightarrow Y 1$ & 0.022560 & 0.009710 & 2.323306 & 0.0244 \\
\hline \hline Variable & Coefficient & Std. Error & t-Statistic & Prob. \\
\hline \hline$C$ & 0.287228 & 0.088288 & 3.253319 & 0.0021 \\
$X \rightarrow Y 2$ & -0.059744 & 0.025153 & -2.375211 & 0.0216 \\
\hline \hline
\end{tabular}

\section{Sumber: Data di Olah Eviews 7}

Dari tabel tersebut terlihat bahwa terdapat $t_{\text {hitung }}$ untuk setiap variabel sedangkan $\mathrm{t}_{\text {tabel }}$ diperoleh melalui tabel $\mathrm{t}(\alpha: 0.05$ dan df : $\mathrm{n}-1)$ sehingga $\alpha: 0.05$ dan Df : 50-1 = 49 maka diperoleh nilai $t_{\text {tabel }}$ sebesar 2,323. Maka dapat diambil simpulan variabel environmental performance adalah nilai $t_{\text {hitung }}$ sebesar 2,323 yang artinya bahwa $t_{\text {hitung }}>$ $\mathrm{t}_{\text {tabel }}(2,323>2,009)$ dan tingkat signifikan sebesar $0,024<0.05$, dengan demikian $\mathrm{H}_{\mathrm{o}}$ ditolak dan $\mathrm{H}_{\mathrm{a}}$ diterima yang bermakna bahwa ada pengaruh Environemntal Performance terhadap Environmental Disclosure. Sedangkan Hipotesis ke dua terlihat bahwa terdapat $t_{\text {hitung }}$ untuk setiap variabel sedangkan $t_{\text {tabel }}$ diperoleh melalui tabel $t(\alpha$ : 0.05 dan df : $n$-1) sehingga $\alpha: 0.05$ dan Df : 50-1 = 49 maka diperoleh nilai $t_{\text {tabel }}$ sebesar 2,375. Maka dapat diambil simpulan variabel environmental performance adalah nilai $\mathrm{t}_{\text {hitung }}$ sebesar $-2,375$ mutlak menjadi 2,375 yang artinya bahwa $\mathrm{t}_{\text {hitung }}>\mathrm{t}_{\text {tabel }}(2,375>$ 2,009) dan tingkat signifikan sebesar $0,022<0.05$, dengan demikian $\mathrm{H}_{\mathrm{o}}$ ditolak dan $\mathrm{H}_{\mathrm{a}}$ diterima yang bermakna bahwa ada pengaruh Environmental Performance terhadap Economic Performance.

\section{Pembahasan}

Tabel uji $\mathrm{t}$ di atas secara statistik menunjukkan bahwa $\mathrm{t}_{\text {Hitung }}$ sebesar 2,323>t $\mathrm{t}_{\text {Tabel }}$ sebesar 2,009. Dengan signifikansinya lebih kecil dari $0,05 \quad(0,024<0,05)$. Ini menunjukkan bahwa variabel independen berpengaruh terhadap variabel dependen. Dimana peran perusahaan dalam kinerja lingkungan membuat image positif bagi perusahaan sehingga dapat menarik para investor untuk bekerja sama dan menanamkan sahamnya pada perusahaan. Hasil penelitian ini mendukung penelitian Suratno, dkk. (2006), Alviana (2012) dan Rohmah (2015) yang menemukan adanya pengaruh signifikan environmental performance terhadap environmental disclosure karena informasi mengenai aktivitas atau kinerja perusahaan adalah hal yang sangat penting bagi stakeholder khususnya investor sebab pengungkapan informasi mengenai hal tersebut merupakan kebutuhan bagi stakeholder. Hal ini menandakan bahwa tinggi rendahnya environmental disclosure dipengaruhi oleh peringkat PROPER yang diperoleh perusahaan tersebut. Semakin tinggi peringkat PROPER yang diperoleh perusahaan, maka semakin besar keinginan perusahaan untuk melakukan pengungkapan. Simpulannya Environmental Performance berpengaruh terhadap Environmental Disclosure, sehingga $\mathrm{H}_{1}$ dalam penelitian ini diterima.

Tabel uji $t$ di atas secara statistik menunjukkan bahwa $t_{\text {Hitung }}$ sebesar 2,375 $>t_{\text {Tabel }}$ sebesar 2,009. Dengan signifikansinya lebih kecil dari $0,05 \quad(0,022<0,05)$. Ini menunjukkan bahwa variabel independen berpengaruh terhadap variabel dependen. 
Dengan peran perusahaan dalam kinerja lingkungan membuat image positif bagi perusahaan sehingga dapat menarik para investor untuk bekerja sama dan menanamkan sahamnya pada perusahaan. Hasil ini mendukung penelitian Suratno, dkk. (2006) dan Alviana (2012). Hal ini mengindikasikan masyarakat merespon baik kinerja lingkungan yang dijalankan oleh perusahaan, sehingga meningkatkan aktivitas ekonomi perusahaan. Simpulannya environmental performance berpengaruh terhadap economic performance, sehingga $\mathrm{H} 2$ dalam penelitian ini diterima.

\section{Simpulan dan Saran}

Penelitian ini bertujuan untuk membuktikan secara empiris pengaruh environmental performance terhadap environmental diclosure dan economic performance. Variabel dalam penelitian ini terdiri dari variabel dependen adalah environmental diclosure dan economic performance, dan variabel independennya adalah environmental performance. Sampel Penelitian berjumlah 10 perusahaan Pertambangan yang terdaftar di Bursa Efek Indonesia pada 2011 -2015. Jenis data yang digunakan dalam penelitian ini adalah data sekunder. Metode pengumpulan data adalah Purposive Sampling. Hasil penelitian menunjukkan bahwa environmental performance berpengaruh secara signifikan terhadap environmental diclosure dan economic performance. Penelitian yang akan datang sebaiknya menggunakan sampel perusahaan yang lebih banyak dan rentang waktu yang lebih lama agar hasil pengujian lebih akurat.

\section{Daftar Pustaka}

Al-Tuwaijri, S.A., Christensen, T.E. dan Hughes II, K.E. 2004. "The Relations among environmental disclosure, environmental performance, and economic performance: a simultaneous equations approach". Accounting, Organizations and Society. Vol. 29. pp.447-471.

Fitriana, Anis, 2013. "Pengaruh Kinerja Lingkungan dan Hard Environmental Disclosure Terhadap Return Saham". Jurnal Fakultas Ekonomi dan Bisnis. Semarang: Universitas Negeri Semarang.

Hadi, Nor. (2011). Corporate Social Responsibility edisi Pertama. Yogyakarta : Graha Ilmu.

Handayani, Ari, Retno, 2010. "Pengaruh Environmental Performance Terhadap Environmental Disclosure dan Economic Performance Serta Environmental Disclosure Terhadap Economic Performance”. Skripsi tidak dipublikasikan. Semarang: Universitas Diponegoro.

Harahap, Sofyan Syafri, 2011. "Teori Akuntansi”. Jakarta: Rajawali Pers.

Ingram, R., \& Frazier, K. 1980. Environmental performance and corporate disclosure. Journal of Accounting Research.p.612-622.

Laporan Tahunan. Kementerian Lingkungan Hidup. 2014

Suratno, Darsono, dan Mutmainah, S, 2006, "Pengaruh Environmental Performance Terhadap Environmental Disclosure dan Economic Performance". Simposium Nasional Akuntansi IX. Padang, 23-26 Agustus 2006.

O’Donovan, Gary. 2002. "Environmental Disclosures in The Annual Report: Extending The Applicability and Predictive Power of Legitimacy Theory". Accounting, Auditing, and Accountability Journal, Vol. 15, No.3, pp. 344-371. 
Patten, D. 1991. Exposure, Legitimacy, and Social Disclosure.Journal of Accounting and Public Policy.p.297-308.

Rochmah, Ibrotul L dan Wahyudin, Agus. 2015. Pengaruh Environmental Performance Terhadap Economic Performance dengan Environment Disclosure sebagai Variabel Intervening (Studi Empiris Pada Perusahaan Manufaktur yang Terdaftar Di Bursa Efek Pada Tahun 2010-2012).Accounting Analysis Journal.

Sindonews.com. Vol.4 No.1 Pg.1-13

Wibisonom, AdiGunawan, 2010. "Pengaruh Environmental Performanc dan Environmental Disclosure Terhadap Economic Performance Pada Perusahaan Pertambangan Dan Pemegang HPH/HPHTI yang Terdaftar di BEI." Skripsi. Yogyakarta: UniversitasNegeri Yogyakarta.

www.mnlh.go.id

\section{Lampiran}

Dependent Variable: Y1

Method: Least Squares

Date: 04/11/17 Time: 11:07

Sample: 150

Included observations: 50

\begin{tabular}{lrllr}
\hline \hline \multicolumn{1}{c}{ Variable } & Coefficient & Std. Error & t-Statistic & Prob. \\
\hline \multicolumn{1}{c}{ C } & 0.323746 & 0.034082 & 9.498942 & 0.0000 \\
\multicolumn{1}{c}{ X Y1 } & 0.022560 & 0.009710 & 2.323306 & 0.0244 \\
\hline \hline R-squared & 0.101086 & Mean dependent var & 0.401351 \\
Adjusted R-squared & 0.082358 & S.D. dependent var & 0.049988 \\
S.E. of regression & 0.047886 & Akaike info criterion & -3.200820 \\
Sum squared resid & 0.110066 & Schwarz criterion & -3.124339 \\
Log likelihood & 82.02050 & Hannan-Quinn criter. & -3.171696 \\
F-statistic & 5.397749 & Durbin-Watson stat & 1.918656 \\
Prob(F-statistic) & 0.024446 & & \\
\hline \hline
\end{tabular}

Dependent Variable: Y2

Method: Least Squares

Date: 04/11/17 Time: 11:08

Sample: 150

Included observations: 50 
Jurnal Akuntansi Vol.9 No.1 Mei 2017: 1 - 11

\begin{tabular}{lrllr}
\hline \hline \multicolumn{1}{c}{ Variable } & Coefficient & Std. Error & t-Statistic & Prob. \\
\hline \multicolumn{1}{c}{ C } & 0.287228 & 0.088288 & 3.253319 & 0.0021 \\
\multicolumn{1}{c}{$\rightarrow$ Y2 } & -0.059744 & 0.025153 & -2.375211 & 0.0216 \\
\hline \hline R-squared & 0.105173 & Mean dependent var & 0.081707 \\
Adjusted R-squared & 0.086530 & S.D. dependent var & 0.129786 \\
S.E. of regression & 0.124044 & Akaike info criterion & -1.297181 \\
Sum squared resid & 0.738573 & Schwarz criterion & -1.220700 \\
Log likelihood & 34.42953 & Hannan-Quinn criter. & -1.268057 \\
F-statistic & 5.641627 & Durbin-Watson stat & 1.453005 \\
Prob(F-statistic) & 0.021581 & & \\
\hline \hline
\end{tabular}

